\title{
CURRENT POSSIBILITIES OF MUSEOLOGY EDUCATION IN SLOVAKIA
}

\author{
PAVOL TIŠLIAR
}

\section{ABSTRACT/ABSTRAKT:}

In the past few years, museology education in Slovakia underwent significant changes, which ended with constitution of the third, doctoral (PhD.), degree of museology studies at the Comenius University in Bratislava. The paper is dealing with the relationship between museum theory and museum practice in the area of university education in the Slovak Republic and defines the basic objectives of museology studies. It describes the existing three-degree system of studies and the newly accredited doctoral (PhD.) studies in museology.

\section{Súčasné možnosti muzeologického vzdelania na Slovensku}

Muzeologická príprava na Slovensku v posledných rokoch zaznamenala výrazné zmeny, ktoré sa zavŕšili predovšetkým vznikom tretieho $\mathrm{PhD}$. stupňa štúdia muzeológie na Univerzite Komenského v Bratislave. Príspevok sa zaoberá vztahom múzejnej teórie a praxe v oblasti univerzitného vzdelávania v Slovenskej republike s vytýčením základných cielov štúdia muzeológie. Poukazuje na existujúci systém trojstupňového štúdia a naplnenia predovšetkým nového akreditovaného doktorandského (PhD.) štúdia muzeológie.

\section{KEYWORDS/KLÚČOVÉ SLOVÁ:}

museology - museum studies doctoral studies in museology Slovakia muzeológia - múzejná štúdia doktorandské štúdium muzeológie Slovensko

\section{On the relationship between theory and practice in museums}

The development of theoretical and methodological foundations in each scientific discipline requires an adequate terminology and other requisites, as well as a well-functioning educational system. In other words: it requires a system and method, with the help of which a sum of certain knowledge is communicated and transferred to next generations. It is true that the development of science can depend on individuals, but when we pursue a permanent and continuous development of science, we must logically build up a complex education system, which not only provides for training of professionals for the practice, but also develops theoretical thinking and methodology in the narrower sense of the word.

The importance of museology education for the practice has been given an increased attention in the past few years. ${ }^{1}$ Among

\footnotetext{
1 E. g. DUBUC, Élise. Museum and university mutations: the relationship between museum practices and museum studies in the era of interdisciplinarity, professionalisation, globalisation and new technologies. Museum Management and Curatorship, 2011, pp. 497-508; MACLEOD, Suzanne. Making Museum Studies: Training, Education, Research and Practice. Museum Management and Curatorship, 2001, pp. 51-61; KAČíREK, Luboš and Pavol TIŠLIAR. Výučba múzejnej pedagogiky v študijnom programe Muzeológia a kultúrne dedičstvo na FiF UK v Bratislave - teória a prax. Muzeológia a kultúrne dedičstvo, 2014, vol. 2, no. 1, pp.
}

the most discussed problems are: implementation of museum theory in museum practice, relevance of methodological procedures and approaches and their direct implementation in individual activities of museum work. ${ }^{2}$ Here also is the basis of a potential contradiction, which we often encounter in the museum practice not only in Slovakia. To what extent is museology actually usable in practice? Theoretical museology represents the foundation of museum work and the theory of museum science. ${ }^{3}$

\footnotetext{
73-91; TIŠLIAR, Pavol. Muzeológia na Slovensku. Muzeológia a kultúrne dedičstvo, 2016, vol. 4, no. 1, pp. 127-135; TIŠLIAR, Pavol. Museology as a university subject in Slovakia history, program and course design. European journal of contemporary education, 2017, vol. 6, no. 1, pp. 159-166. From the most recent works we can name for example KIRSCH, Otakar and Lucie JAGOŠOVÁ. Towards professionalism through academic education in museum work: on the beginnings of museology education in Czech universities. Museum Management and Curatorship, 2019, pp. 1-15; THOMAS, Suzie, Anna WESSMAN and Eino HEIKKILÄ. Redesigning the museum studies programme at the University of Helsinki: towards collaborative teaching and learning. Museum Management and Curatorship, 2018, pp. $1-21$.

2 In more detail e. g. THOMAS, Suzie, Anna WESSMAN and Eino HEIKKILÄ. Redesigning the museum studies programme at the University of Helsinki: towards collaborative teaching and learning. Museum Management and Curatorship, 2018, p. 2; MCCARTHY, Conal. Theorising Museum Practice Through Practice Theory: Museum Studies as Intercultural Practice. In BURNARD, Pamela, Elizabeth MACKINLAY and Kimberly POWELL (eds.). The Routledge International Handbook of International Arts Research. Abingdon: Routledge, 2016, pp. 24-34; HOHENSTEIN, Jill and Theano MOUSSOURI. Museum Learning: Theory and Research as Tool for Enhancing Practice. Ambigdon: Routledge, 2018.

3 STRÁNSKÝ, Zbyněk Z. Úvod do studia muzeologie. Brno: Masarykova univerzita, 2000, p. 31; WAIDACHER, Friedrich. Príručka všeobecnej muzeológie. Bratislava: Slovenské národné múzeum, 1999, p. 97; also e. g. Museologie: Theoretische Grundlagen und Methodik der Arbeit in Geschichtsmuseen. Berlin: VEB, 1988, p. 29 sq.;
} 
Z. Z. Stránský, whose theoretical concept represents one of the basic starting points of museology studies in Slovakia, saw the domain of this discipline in the identification of motivations for a specific relationship of humans to reality. He divided the system of museology into the theories of selection, thesauration and presentation, ${ }^{4}$ which at the methodological level help to fulfil the basic mission of museums in the practice. In the system of museology he also included the historical and the applied museology. ${ }^{5}$ The former branch pays attention to the development of museum phenomenon and its relation to the society, whereas applied museology (museography) represents a set of practical techniques for the implementation of museum activities, such as museum exhibitions, museum communication, preservation and institutionalisation (museum management and marketing).

Today few doubt that the museum work is mainly represented by a system of multiple professional activities, which are targeted above all at protection, administration, presentation and scientific exploration of cultural and natural heritage. These activities naturally require specific education, professionalisation, during which the student learns about various approaches, procedures and methods, gains an overview and knowledge of principles of exhibition making, terminology, legislation, management and marketing of cultural institutions, as well as of new trends in individual professional activities, etc. It is true, and it was already

\footnotetext{
also BENEŠ, Josef. Základy muzeologie. Opava:

Slezská univerzita v Opavě, 1997, p. 37.

4 STRÁNSKÝ, Zbyněk Z. Úvod do studia muzeologie. Brno: Masarykova univerzita, 2000,

p. 39 sq.

5 STRÁNSKÝ, Zbyněk Z. Archeologie a muzeologie. Brno: Masarykova univerzita, 2005, p. 129.
}

emphasized by many authors, ${ }^{6}$ that the study of specialised, i.e. applied, scientific disciplines, ${ }^{7}$ such as archaeology, history, ethnology, history of art, various natural and technical sciences, etc., does not provide adequate competences for the museum work. Although the knowledge focus of these applied sciences undoubtedly represents a benefit for museums (mainly at the material level), ${ }^{8}$ their curricula do not contain special thematic areas oriented on various aspects of museum work and on the museum phenomenon. An object can mostly be successfully described from the perspective of applied sciences, but at the practical level we encounter a decision-making problem regarding the value of particular objects. So it happens that museums often acquire objects which they actually do not need and, vice versa, exclude things which have certain cultural, historical or aesthetical value for the museum collections. ${ }^{9}$ From this point of view, the professional education in the applied discipline appears incomplete and insufficient in the museum milieu and it requires additional training ${ }^{10}$ in the form of various extension courses

\footnotetext{
6 E. g. STRÁNSKÝ, Zbyněk Z. Úvod do studia muzeologie. Brno: Masarykova univerzita v Brně, 2000, pp. 15-16. Interesting is, for example, a reflection essay by G. Podušelová on education and training of graduates for the practice. The author regards the combined study mode as a sort of ideal. PODUŠELOVÁ, Gabriela. Je možná a potrebná špecializácia vo výuke muzeológie? In Muzeológia: Teória \& prax. Banská Štiavnica: Spoločnosț pre pamiatky a Katedra ekomuzeológie Fakulty prírodných vied Univerzity Mateja Bela, 2006, pp. 49-50.

7 HOLMAN, Pavel. Úvod do muzeologie. In Základy muzejní pedagogiky: Studijní texty. Brno: Moravské zemské muzeum, 2014, pp. 22-23.

8 STRÁNSKÝ, Zbyněk Z. Úvod do studia muzeologie. Brno: Masarykova univerzita, 2000, p. 15.

9 For more details on this problem see DOLÁK, Jan. Sběratelství a sbírkotvorná činnost muzeí: Vysokoškolská učebnice. Bratislava: Univerzita Komenského v Bratislave, 2018.

10 NEUSTUPNÝ, Jiř́i. Otázky dnešního musejnictví: Př́spěvky k obecné a speciální museologii. Praha: Orbis, 1950, pp. 6-7.
}

or the more complex university studies. ${ }^{11}$

Why should the museums actually employ trained graduates? Let us imagine the situation when on-site archaeological excavation would be carried out by an expert in some other related discipline, for example a historian. He might be very well knowledgeable in prehistory, but he does not know the methods, principles, types and requisites of archaeological excavations. The result would be a destroyed archaeological site. Cultural or natural heritage would suffer irreversible damages. Similar is the case with other branches and disciplines, or with areas which resemble the museum work. Why do we need educated archivists in archives? Why should libraries employ educated bibliographers and specialists in information systems? The reason might be that we care a lot about proper functioning of the bibliographic and information system of libraries, which should serve the public. Archival documents and collections should be properly stored and made accessible to professional community for the purpose of scientific and systematic research. It is necessary to secure that archival documents of permanent socio-cultural and documentary value are not discarded and liquidated. The museums curate heritage of irreplaceable and incalculable value. In this context it is therefore also inevitable to pay attention to quality education of

\footnotetext{
11 E. g. MLYNKA, Ladislav. Muzeológia na Filozofickej fakulte UK Bratislava ako študijný odbor. In Muzeológia: Teória \& prax. Banská Štiavnica: Spoločnost’ pre pamiatky a Katedra ekomuzeológie Fakulty prírodných vied Univerzity Mateja Bela, 2006, pp. 66-71; MLYNKA, Ladislav. Muzeológia na prahu tretieho tisícročia. In Múzeá na prahu tretieho tisícročia: zborník príspevkov z konferencie Banská Bystrica 1999. Bratislava: Slovenské národné múzeum-Národné múzejné centrum a Zväz múzeí na Slovensku, 1999, pp. 92-95; KAČÍREK, L’uboš and Pavol TIŠLIAR. Stav a perspektívy štúdia muzeológie na Filozofickej fakulte UK. In Dokumentácia druhej polovice 20. storočia a súčasnosti: Etnológ a múzeum, XV. ročník. Martin, 2012, pp. 135-146.
} 
specialists - museum workers, who are able to evaluate the cultural, educational and leisure potential of the inherited tangible part of cultural memory of society, which is kept in museums.

The implementation of theoretical and methodological museological knowledge in museum practice thus represents one of the significant and, in my opinion, crucial elements of a responsible attitude to the protection, administration and utilization of our heritage. It is necessary to interconnect the theory and practice, to search for their overlaps, and to exert a mutual and joint influence on the development "of both sides of the same coin".

\section{The system of museology education at Slovak universities and its future perspectives}

It is necessary to build up a quality education system based on the above-mentioned principles. It should prepare specialists for the practice, who will be able to apply the acquired theoretical knowledge in museums and will help to fulfil the fundamental tasks of museum institutions. Museum studies and museology are currently studied at as good as all significant universities worldwide, in various modes and degrees of study, but also as a combined interdisciplinary study or as a separate study field. In the Slovak Republic, complete museological education is provided solely by the Faculty of Arts of the Comenius University in Bratislava, in all three degrees of study. The aim of this paper is not to analyse in detail the content of individual degrees of study programmes. ${ }^{12}$ The Bachelor's

\footnotetext{
12 On the history of museology studies in Slovakia see MLYNKA, Ladislav. Výuka etnomuzeológie. Význam, súčasný stav a perspektívy. Múzeum, 1997, vol. 43, no. 2, pp. 24-25; MLYNKA, Ladislav. Muzeológia na Filozofickej fakulte UK Bratislava ako študijný odbor. In Muzeológia: Teória \& prax. Banská
}

studies in Bratislava generally accentuate the museographic (applied) aspect of museum work, where the main focus is laid on museography, collection-building activity, museum communication, conservation and history of museums. The Bachelor's degree programme offers not only the single-field study Museology and cultural heritage, which pays one-third of its attention to the protection of monuments - cultural heritage in general. It also offers studies in interdisciplinary combinations: museology with history, ethnology (ethnography), history of art, library and information science. The separate study of museum pedagogy currently undergoes the accreditation process. The second degree of study is represented by the follow-up Master's studies, which are characterised by their orientation on museological issues. The main focus is laid on theoretical museology, museum exhibitions, management and marketing of cultural institutions. In both of the above-mentioned

\footnotetext{
Štiavnica: Spoločnost pre pamiatky a Katedra ekomuzeológie Fakulty prírodných vied Univerzity Mateja Bela, 2006, pp. 66-71; KAČÍREK, L’uboš and Pavol TIŠLIAR. Výučba múzejnej pedagogiky v študijnom programe Muzeológia a kultúrne dedičstvo na FiF UK v Bratislave - teória a prax. Muzeológia a kultúrne dedičstvo, 2014, no. 1, pp. 73-91; KAČ́́REK, L'uboš and Pavol TIŠLIAR. The benefit of museum visits for the formal education of children in primary and secondary education in the Slovak Republic. Terra Sebus, 2017, vol. 9, pp. 491-506; TIŠLIAR, Pavol. Muzeológia v akreditačnom období, po novom? Muzeológia a kultúrne dedičstvo, 2014, no. 2, pp. 91-97; KAČíREK, L'uboš and Pavol TIŠLIAR. Koncepcie a východiská štúdia muzeológie a kultúrneho dedičstva na Slovensku. In Muzea a památková péče. Havlíčkův Brod: Muzeum Vysočiny Havlíčkův Brod, 2013, pp. 61-90; KAČ́́REK, Luboš and Pavol TIŠLIAR. Stav a perspektívy štúdia muzeológie na Filozofickej fakulte UK. In Dokumentácia druhej polovice 20. storočia a súčasnosti: Etnológ a múzeum, XV. ročník. Martin, 2012, pp. 135-146; ZELENÝ, Ján. Kultúrne dedičstvo a muzeológia na Katedre enviromentálneho manažérstva. In Múzeum a muzeológia - ich determinanty a perspektívy $v$ kontexte súčasného sveta. Zborník príspevkov vedeckej konferencie 11. a 12. júna 2008. Banská Bystrica: Univerzita Mateja Bela, 2008, pp. 5-9; KAČÍREK, L’uboš and Pavol TIŠLIAR. Desa rokov súčasného interného štúdia muzeológie a kultúrneho dedičstva v Bratislave. Museologica Brunensia, 2016, vol. 5, no. 1, pp. 68-69.
}

degrees of study, theory outweighs practice by a $2: 1$ ratio. The practice is taught in the form of practical seminars. During the five-year studies, students undergo 90 days of practical training in museum institutions, where they actively apply the acquired knowledge in museum work.

The accreditation of doctoral PhD. studies Museology and cultural heritage (2018) completed the long-term objectives of the museology studies in Bratislava. This third degree of study particularly addresses the metamuseological level, which was defined by Z. Z. Stránský as a metatheory, whose subject matter is the museology itself. ${ }^{13}$ Metamuseology judges normatively the implementation of museology, evaluates its objectives, methods, results, definitions and terminology. ${ }^{14}$ The above-mentioned characteristic became the content of new doctoral studies, which are organised at the Comenius University in two basic study modes (full-time study and part-time external study), in Slovak and English language. The main form is the part-time external five-year PhD. museology study, which is open especially to applicants from museum institutions, but also from abroad. The conception of the approved curriculum consists of doctoral seminars, Methodological seminar in theoretical museology 1 and 2, Methodological seminar in monumentology, which are mainly focused on terminology, legislation, definitions and methodology in the field of museums and partly also in the field of monument care. The curriculum also comprises semi-elective doctoral courses, Metamuseological seminar, Musealisation of reality, Museum

\footnotetext{
13 STRÁNSKÝ, Zbyněk Z. Úvod do muzeologie. Brno: Masarykova univerzita, 2000, p. 22.

14 WAIDACHER, Friedrich. Príručka všeobecnej muzeológie. Bratislava: Slovenské národné múzeum, 1999, p. 25.
} 
as an institution - paradigms in the perception of museums and Memory institutions in international context. Doctoral studies should extend the knowledge of students in theoretical and methodological areas of museology, museum studies and monumentology, which are applicable in the museum practice. The constitution of the third degree of museology studies offers a possibility to educate future lecturers and scientific workers in the field of museology, and ensures the continuity of museology studies in accordance with legislative regulations and conditions in the Slovak Republic. In the future, particularly in connection with trends in the museum sphere, we can suppose further development oriented mainly on topics like documentation of the present, efficient and meaningful collectionbuilding and presentation activity, development of educational activity of museums, and promotion of public leisure activities in favour of museum visits.

\section{LITERATURE:}

BENEŠ, Josef. Základy muzeologie. Opava: Slezská univerzita v Opavě, 1997. ISBN 80-901974-3-4.

DOLÁK, Jan. Sběratelství a sbírkotvorná činnost muzeí: Vysokoškolská učebnice. Bratislava: Univerzita Komenského v Bratislave, 2018. ISBN 978-80-223-4553-8.

DUBUC, Élise. Museum and university mutations: the relationship between museum practices and museum studies in the era of interdisciplinarity, professionalisation, globalisation and new technologies. Museum Management and Curatorship, 2011, pp. 497-508. ISSN 1872-9185. https://doi.org/10.1080/096477 75.2011.621734

HOHENSTEIN, Jill and Theano MOUSSOURI. Museum Learning: Theory and Research as Tool for Enhancing Practice. Ambigdon: Routledge, 2018. ISBN 978-1-317-44594-4.
HOLMAN, Pavel. Úvod do muzeologie. In Základy muzejní pedagogiky: Studijní texty. Brno: Moravské zemské muzeum, 2014, pp. 22-23. ISBN 978-80-7028-441-4.

KAČÍREK, L'uboš and Pavol TIŠLIAR. Desat rokov súčasného interného štúdia muzeológie a kultúrneho dedičstva v Bratislave. Museologica Brunensia, 2016, vol. 5, no. 1, pp. 68-69. ISSN 1805-4722.

KAČíREK, Luboš and Pavol TIŠLIAR. Koncepcie a východiská štúdia muzeológie a kultúrneho dedičstva na Slovensku. In Muzea a památková péče. Havlíčkův Brod: Muzeum Vysočiny Havlíčkův Brod, 2013, pp. 61-90.

ISBN 978-80-87302-22-4.

KAČÍREK, Luboš and Pavol TIŠLIAR. Stav a perspektívy štúdia muzeológie na Filozofickej fakulte UK. In Dokumentácia druhej polovice 20. storočia a súčasnosti: Etnológ a múzeum, XV. ročník. Martin, 2012, pp. 135-146. ISBN 978-80-8060-286-4.

KAČÍREK, L’uboš and Pavol TIŠLIAR. The benefit of museum visits for the formal education of children in primary and secondary education in the Slovak Republic. Terra Sebus, 2017, vol. 9, pp. 491-506. ISSN 2066-9143.

KAČÍREK, Luboš and Pavol TIŠLIAR. Výučba múzejnej pedagogiky v študijnom programe Muzeológia a kultúrne dedičstvo na FiF UK v Bratislave - teória a prax. Muzeológia a kultúrne dedičstvo, 2014, vol. 2, no. 1, pp. 73-91. ISSN 1339-2204.

KIRSCH, Otakar and Lucie JAGOŠOVÁ. Towards professionalism through academic education in museum work: on the beginnings of museology education in Czech universities. Museum Management and Curatorship, 2019, pp. 1-15. ISSN 1872-9185. https://doi.org/10.1 080/09647775.2019.1599993

MACLEOD, Suzanne. Making Museum Studies: Training, Education, Research and Practice. Museum Management and Curatorship, 2001, pp. 51-61. ISSN 1872-9185. https://doi. org/10.1080/09647770100501901

McCARTHY, Conal. Theorising Museum Practice Through Practice Theory: Museum Studies as Intercultural Practice. In BURNARD, Pamela, Elizabeth MACKINLAY and Kimberly POWELL (eds.). The Routledge International Handbook of International Arts Research. Abingdon: Routledge, 2016, pp. 24-34. ISBN 978-1-138-90993-9.

MLYNKA, Ladislav. Muzeológia na Filozofickej fakulte UK Bratislava ako študijný odbor. In Muzeológia: Teória \& prax. Banská Štiavnica: Spoločnosť pre pamiatky a Katedra ekomuzeológie Fakulty prírodných vied Univerzity Mateja Bela, 2006, pp. 66-71. ISBN 80-969561-7-5.

MLYNKA, Ladislav. Muzeológia na prahu tretieho tisícročia. In Múzeá na prahu tretieho tisícročia: zborník príspevkov z konferencie Banská Bystrica 1999. Bratislava: Slovenské národné múzeum-Národné múzejné centrum a Zväz múzeí na Slovensku, 1999, pp. 92-95. ISBN 978-80-8060-026-6.

MLYNKA, Ladislav. Výuka etnomuzeológie. Význam, súčasný stav a perspektívy. Múzeum, 1997, vol. 43, no. 2, pp. 24-25. ISSN 0027-5263.

Museologie: Theoretische Grundlagen und Methodik der Arbeit in Geschichtsmuseen. Berlin: VEB, 1988. ISBN 978-3-326-00229-3.

NEUSTUPNÝ, Jiří. Otázky dnešního musejnictví: Příspěvky k obecné a speciální museologii. Praha: Orbis, 1950.

PODUŠELOVÁ, Gabriela. Je možná a potrebná špecializácia vo výuke muzeológie? In Muzeológia: Teória \& prax. Banská Štiavnica: Spoločnost̉ pre pamiatky a Katedra ekomuzeológie Fakulty prírodných vied Univerzity Mateja Bela, 2006, pp. 49-50. ISBN 80-969561-7-5.

STRÁNSKÝ, Zbyněk Z. Archeologie a muzeologie. Brno: Masarykova univerzita, 2005. ISBN 80-210-3861-6.

STRÁNSKÝ, Zbyněk Z. Úvod do studia muzeologie. Brno: Masarykova univerzita, 2000. ISBN 80-210-1272-2.

THOMAS, Suzie, Anna WESSMAN and Eino HEIKKILÄ. Redesigning the museum studies programme at the University of Helsinki: towards collaborative teaching and learning. Museum Management and Curatorship, 2018, pp. 1-21.

ISSN 1872-9185. https://doi.org/10.1080/09 647775.2018.1485115

TIŠLIAR, Pavol. Muzeológia na Slovensku. Muzeológia a kultúrne dedičstvo, 2016, vol. 4, no. 1, pp. 127-135. ISSN 1339-2204. 
TIŠLIAR, Pavol. Museology as a university subject in Slovakia history, program and course design. European journal of contemporary education, 2017, vol. 6, no. 1 , pp. 159-166. ISSN 2305-6746.

TIŠLIAR, Pavol. Muzeológia v akreditačnom období, ponovom? Muzeológia a kultúrne dedičstvo, 2014, vol. 2, no. 2, pp. 91-97. ISSN 1339-2204.

WAIDACHER, Friedrich. Príručka všeobecnej muzeológie. Bratislava: Slovenské národné múzeum, 1999.

ISBN 80-8060-015-5.

ZELENÝ, Ján. Kultúrne dedičstvo a muzeológia na Katedre enviromentálneho manažérstva. In Múzeum a muzeológia - ich determinanty a perspektívy $v$ kontexte súčasného sveta. Zborník príspevkov vedeckej konferencie 11. a 12. júna 2008. Banská Bystrica: Univerzita Mateja Bela, 2008, pp. 5-9. ISBN 978-80-8083-596-5.

\section{PAVOL TIŠLIAR}

Department of Archeology

and Museology, Faculty of Arts,

Masaryk University, Brno,

Czech Republic;

Department of Ethnology

and Museology, Faculty of Arts,

Comenius University in Bratislava,

Slovak Republic

tisliar@phil.muni.cz

Pavol Tišliar is professor of

Slovak history. He works at the

Department of Archeology and Museology at the Faculty of Arts, Masaryk University in Brno and at the Department of Ethnology and Museology at the Faculty of Arts, Charles University in Bratislava. He publishes the history of museums (museology) and monumentology, theoretical problems of cultural heritage and as a historian also in the field of socio-cultural history of Slovakia.

Pavol Tišliar je profesorom slovenských dejín. Pôsobí na Ústave archeologie a muzeologie Filozofickej fakulty Masarykovej univerzity v Brne a na Katedre etnológie a muzeológie Filozofickej fakulty Univerzity Komenského v Bratislave. Publikuje z oblasti dejín múzejníctva a monumentológie, teoretických problémov kultúrneho dedičstva a ako historik aj v oblasti socialnokultúrnych dejín Slovenska. 